\title{
O plawieniu czarownic w Gdowie w 1689 r. Kartka $z$ dziejów miejskiego procesu karnego w Polsce
}

\section{Vom Hexenschwemmen in Gdów im Jahre 1689. Ein Blatt aus der Geschichte städtisches Strafprozesses in Polen}

1. Pławienie czarownic w historiografii polskiej. 2. Proces gdowskich „czarownic" z $1689 \mathrm{r}$. 3. Potrzeba weryfikacji poglądu o stosowaniu pławienia czarownic w Polsce. 4. Brak wyczerpującego opracowania problematyki oskarżeń o czary.

1. Hexenschwemmen in polnischer Historiografie. 2. Hexenprozess in Gdowo im Jahre 1689. 3. Das Bedürfnis nach der Verifikation der Ansicht über die Anwendung des Hexenschwemmens in Polen. 4. Keine ausführliche Bearbeitung der Problematik der Anklage wegen Zauberei.

1. Mimo iż w Polsce, podobnie jak i w większości krajów europejskich, sądy boże jako instytucja prawa procesowego zdążyły zaniknąć zanim średniowiecze weszło w swój schyłkowy okres, to jednak sama wiara $\mathrm{w}$ interwencje sił nadprzyrodzonych umożliwiającą wskazanie winnego zbrodni przetrwała do czasów nowożytnych. Bardzo długo np. utrzymywało się przekonanie, iż zwłoki zamordowanego niechybnie wydadzą zabójcę, jeżeli tylko znajdzie się on w pobliżu ciała swej ofiary'. I choć zapewne nie wszyscy podzielali ów pogląd, zaś działający na przełomie XVI i XVII w. prawnik Adam Żydowski nazwał go wrecz niebezpiecznym wymysłem², to

\footnotetext{
${ }^{1} \mathrm{~W}$ zachodniej Europie wiara $\mathrm{w}$ krwawienie ran zabitego $\mathrm{w}$ razie zbliżenia się doń mordercy i związana $z$ nią tzw. próba mar przetrwały aż do polowy XVIII w. Zob. W. M a isel, Archeologia prawna Europy, Warszawa 1989, s. 188-189; por. również Ph. A ries, Czlowiek i śmierć, przel. E. Bąkowska, Warszawa 1992, s. 348, a także L. V. Thomas, Trup. Od biologii do antropologii, Lódź 1991, s. 30.

${ }^{2}$ Por. Także in homicidio biora to pro indicio, gdy za przyściem czyim do zabitego tunie sie krew $z$ trupa, albo jako krzyknie, jakoby winowajce onego ukazuje $i$ wydaje, ale to niebezpieczny wymysl $i$ niepewne ad torturam indicium. Dalej A. Żydowski stwierdzal zresztą, że przeprowadził był nawet odpowiedni eksperyment: Próbowalem ja raz tego umyślnie; kazalem przywieść zabójce do trupa; nie wystapila by najmniejsza krople krwie z niego (rkps w Bibliotece PAN w Krakowie [dalej: PAN Kr.], sygn. 1259 (Opera in iure Adami Żydowski), k. 83).
} 
jeszcze w latach pięćdziesiątych XVIII w., w sprawach o mordy rytualne, „wskazanie" przestępców przez krew plynącą z ran zabitych dzieci traktowano jako jeden $\mathrm{z}$ najlepszych dowodów ich winy ${ }^{3}$. Jednak najlepiej chyba znanym reliktem średniowiecznych ordaliów było plawienie czarownic. Próba, polegająca na spuszczaniu na wodę związanych uprzednio kobiet, opierała się na założeniu, iż lżejsza od wody czarownica utrzyma się na jej powierzchni, podczas gdy osoba niesłusznie pomówiona będzie tonąć. Nie była to więc jedynie kontynuacja średniowiecznej próby zimnej wody, lecz - $\mathrm{i}$ to może nawet przede wszystkim - prymitywna forma sprawdzenia wagi ciała, która w przypadku osób uprawiających czary zupełnie ponoć nie odpowiadała ich posturze ${ }^{4}$.

Spośród historyków badających dzieje polskich procesów o czary, najobszerniejsze jak do tej pory uwagi o plawieniu podejrzanych dał Bohdan Baranowski w swej opublikowanej w 1952 r. książces. Uczony ten znał i przytaczał stosunkowo liczne przykłady staropolskich opracowań, których autorzy $\mathrm{z}$ dezaprobatą wypowiadali się o takim sposobie udowadniania „czarostwa”, stwierdzał jednak, iż mimo owych głosów krytycznych, zwyczaj pławienia był w Polsce tak powszechny, że spotykamy się z nim na każdym kroku. Co więcej, B. Baranowski przyjmowal, że próba ta stanowiła element większości, a może nawet wszystkich odbywających się w Polsce procesów o czary, choć jednocześnie za pomocą przypisów udokumentował zaledwie kilka przypadków puszczania na wode domniemanych czarownic. Ponadto tylko w dwóch opisywanych przezeń sprawach informacje zaczerpnięto $\mathrm{z}$ akt sądowych; dane o innych czterech pochodzą $\mathrm{z}$ różnych kronik i opisów - współczesnych, ale i dziewiętnastowiecznych, w tym z mocno wątpliwej ${ }^{6}$ relacji o straceniu czarownic w Dorucho-

\footnotetext{
${ }^{3}$ Por. sprawę rozpatrywaną przez sąd grodzki w Żytomierzu w 1753 r.: znalezione zwłoki dziecka niesiono do cerkwi $i$ przechodzqc kolo tej karczmy, $w$ której umęczone bylo, krew sie $z$ boku lewego, z owej najpierwszej rany puscila $i$ tak z tego, jak $i$ z innych na Żydów suspicyi zaraz w tej wsi wzięto dwóch Żydów karczmarzów (Dekret o zamęczenie przez Żydów dziecięcia katolickiego ferowany w grodzie żytomirskim [b. m. i r. w.], brak paginacji [k. 1-1v.]. Zob. też sprawę toczącą się w Przemyślu w 1759 r. (Z. Guld on, J. W j j a czk a, Procesy o mordy rytualne w Polsce w XVI-XVIII wieku, Kielce 1995, s. 63).

${ }^{4}$ Przeświadczenie o niezwykłej lekkości czarowników i czarownic legło także u podstaw próby ważenia przeprowadzanej w Holandii, a podobno i w innych krajach Europy (W. M a is el, Archeologia..., s. 189; zob. też K. B a schwit z, Czarownice. Dzieje procesów o czary, przekł. T. Zabłudowski, Warszawa 1971, s. 325-337).

${ }^{5}$ B. Bara nowski, Procesy czarownic w Polsce w XVII i XVIII wieku, Lódź 1952, s. 89-96. Zob. także popularnonaukowe prace tego $\dot{z}$, Życie codzienne malego miasteczka $w$ XVII $i$ XVIII wieku, Warszawa 1975 , s. 225-227, oraz O hultajach, wiedzmach $i$ wszetecznicach. Szkice $z$ obyczajów XVII $i$ XVIII w., Lódź 1988, s. 116-119.

${ }^{6}$ Zob. J. Michalski, Jeszcze o konstytucji sejmu 1776 roku „Konwikcje $w$ sprawach kryminainych", KH 1996, z. 3, s. 93-94.
} 
wie ${ }^{7}$. Dodajmy, że również reszta stosunkowo licznych, choć na ogół drobnych i przyczynkarskich prac poświęconych procesom czarownic, a także wydawnictwa źródłowe dostarczają jedynie sporadycznych wzmianek o poddawaniu podejrzanych próbie pławienia ${ }^{8}$. Mimo to podręczniki historii prawa - prawdopodobnie za B. Baranowskim - wyraźnie uznają próbę wody za podstawowy składnik procesów o czary i równorzędny torturom sposób udowadniania wspólpracy z szatanem? ${ }^{9}$.

Tak daleko idące uogólnienie przy jednoczesnej słabej bazie faktograficznej budzi pewne wątpliwości, dlatego warto chyba przyjrzeć się bliżej jednej ze spraw o czary, w której pojawił się problem wykorzystania pławienia jako dowodu winy.

2. W Bibliotece Polskiej Akademii Nauk w Krakowie przechowywana jest niewielka, licząca 125 kart księga miejska. Rękopis ów stanowi rodzaj brulionu, raptularza służącego do zapisywania rozmaitych, zarówno karnych, jak i cywilnych spraw toczących się przed wójtowskim i radzieckim urzędem miasta Dobczyc w latach 1687-168910. Na kilku kartach owej księgi znajdują się notatki dotyczące interesującego nas procesu, toczącego się zresztą nie w samym miasteczku, lecz w pobliskim Gdowie ${ }^{11}$.

${ }^{7}$ B. B a ran owski, Procesy czarownic..., s. 91-95. Autor ten wspomina jeszcze o dwóch bądź trzech zupełnie już bezprawnych przypadkach pławienia z końca XVIII i z XIX stulecia (ibidem, s. 95-96).

${ }^{8}$ Słyszymy np. o pławieniu czarownic w Pilicy lub jej okolicach w 1645 r. (K. Buk ow sk a - Gorgoni, Procesy o czary $i$ powolania przez czarownice $w$ orzecznictwie Sqdu Wyższego Prawa Niemieckiego na zamku krakowskim, Lud 1970, t. LIV, s. 165, nr 7), w bliżej nieokreślonej podlubelskiej wiosce w 1647 r. (M. Dąbrowska-Zakrzewska, Procesy o czary $w$ Lublinie $w$ XVII $i$ XVIII w., Lublin 1947, nr 9), w Praszce w r. 1665 (B. B a ra nowski, Wielki proces o czary milosne $w$ Praszce $w 1665$ r., Lódzkie Studia Etnograficzne 1962, t. IV, s. 11), w jakiejś wsi w pobliżu Slomnik w 1674 r. (W. S i a r k ow ski, Materialy do etnografii ludu polskiego z okolic Kielc, cz. II, Zbiór Wiadomości do Antropologii Krajowej 1879, t. III, s. 34-35, nr I), w Rakoszynie koło Szczekocin w 1706 r. (ibidem, s. 40, nr IV), wreszcie w Rzeszowie, również na początku XVIII w. (Z. D y da k, Czary $w$ procesie inkwizycyjnym $w$ Rzeszowie $w$ XVIII wieku, Rocznik Województwa Rzeszowskiego 1964 1965, R. V, s. 386). Zob. również L. A. J u cewicz, Wspomnienia Żmudzi, Wilno 1842, s. 185-186, 204 (Dodatek C: Dekrety na czarowników, nr II - 1692 r.; $\mathrm{V}-1696$ r.).

${ }^{9}$ Zob. K. B uk owska, Proces w prawie miejskim, [w:] Historia państwa i prawa Polski, t. II, Warszawa 1971, s. 429; J. B a rd a ch, [w:] J. B ard a ch, B. Leśnod or ski, M. P i elrzak, Historia państwa i prawa polskiego, Warszawa 1993, s. 281; zob. też S. P ł a za, Historia prawa w Polsce na tle porównawczym, cz. I: X-XVIII w., Kraków 1997, s. 473; K. Sojjk a - Zi elińsk a, Historia prawa, Warszawa 1993, s. 210.

${ }^{10}$ PAN Kr. 594. Zawartość księgi określono $\mathrm{w}$ kacińskim nagłówku na k. 1.

"PAN Kr. 594, k. 105v,-107v. 
Dobczycki sąd miejski 27 maja 1689 r. zjechał do Gdowa, by rozpatrzyć sprawę podejrzanych o czary kobiet: Rejny (Reginy) Krawcowej i Heleny Gałczyny. Sędziów sprowadzil prawdopodobnie właściciel wioski, aresztowane oskarżone przetrzymywano bowiem we dworze, zaś z zeznań jednego ze świadków wynikałoby, że to przede wszystkim pan upatrywał $w$ obu kobietach czarownice ${ }^{12}$. W aktach nie odnotowano składu sądu, nie wiadomo zatem, czy zasiadali w nim wyłącznie czlonkowie władz miejskich, czy też dokooptowali oni do swego grona przedstawicieli miejscowego sądu wiejskiego ${ }^{13}$.

Postępowanie rozpoczęło przesłuchanie świadków, czyli tak zwana inkwizy$\mathrm{cja}^{14}$. Z zeznań wynikało, iż przeszło dwa lata wcześniej niejaki Michał Kania dostał w Bilczycach od tamtejszego sadownika trochę jabłck, przyniósł je do Gdowa i tu na prośbę znanej nam już Rejny Krawcowej dał jej owe jabłka za garnuszek słodkiego mleka. Następnie Kania udał się do domu swego syna, tam wypił część mleka, resztę przelał do innego naczynia, zaś pożyczony od Krawcowej garnuszek zaniósł właścicielce. Gdy następnego dnia sięgnął po owo przelane w inszy garczek mleko, okazalo się, że na samym dnie bylo (salvis auribus) lajno, jakby końskie. Synowa Kani kazała mu wylać mleko, co on skwapliwie uczynil, zaś po kilkunastu tygodniach, gdy po wsi rozeszla się wieść o dziwnym wydarzeniu, do domu Kaniów przyszła Krawcowa, tłumacząc się, że nie ma w nim nic nadzwyczajnego; po prostu krowy nie omyla i mleka nie przeczedzila, $i$ tak sie na spodku ustalo. Pytany przez sąd Kania, jeżeliby to za czary poczytal, albo dowodzić chcial, zaprzeczył, mówiąc, że nic z tego o czarach nie rozumie na tę Krawcowa ${ }^{15}$.

${ }^{12}$ PAN Kr. 594, k. 106v. Maciej Włodarz przytoczył słowa dziedzica wypowiedziane podczas plawienia: rzekl mi jegomość - Otoż macie czarownice (PAN Kr. 594, k. 107).

${ }^{13}$ Takie łączenie obu sądów, miejskiego i wiejskiego, dość często występowało w praktyce. Zob. np. R. Laszewski, Wiejskie prawo karne w Polsce XVII i XVII wieku, Toruń 1988, s. 37; S. G rodziski, [Wstep do:] Ksiegi sqdowe klucza jazowskiego 1663-1808, oprac. S. Grodziski, Wrocław-Warszawa-Kraków 1967, s. 22; por. również B. B a r a n o w s k i, Procesy czarownic..., s. 78.

${ }^{14} \mathrm{~W}$ protokołach spraw kryminalnych rozpoznawanych zarówno przez sąd dobczycki, jak i inne sądy miejskie niejednokrotnie na początku odnotowywano wystąpienie ze skargą przez powoda; por. np. PAN Kr. 591 (Dobczyce), k. 72 (176! r.); PAN Kr. 594 (Dobczyce), k. 60v.-6l (1688 r.); rkps w Archiwum Państwowym w Krakowie, oddział na Wawelu [dalej: APKr./W.], Akta depozytowe [dalej: AD], sygn. 67 (Dobczyce), s. 23 (1701 r.), 40.42 (1702 r.); rkps w Bibliotece Jagiellońskiej w Krakowie [dalej: BJ], sygn. 86 (Miechów), k. 44v. (1617); BJ 122 (Nowa Góra), k. 3-3v. (1587 r.) itp. Akta omawianej sprawy nie wspominają o wygloszeniu skargi, co nie musi oznaczać, że jej nie było. Możliwe jednak, że w tym wypadku samo ściągnięcie sądu do rozpoznania sprawy mogło zastępować formalne wniesienie oskarżenia.

15 PAN Kr. 594, k. 105v. (zeznanie Michała Kani); 106 (zeznanie Sebastiana Ptaszewskiego, który jednak widział na dnie garnka nie łajno, lecz coś w rodzaju posiekanej zielonej trawy'), 106v.-107 (zeznania Rejny (Reginy), synowej Kani, Rejny Jamczyny, Jacka Wywisłka, Stanisława Jamki, Andrzeja Kucharza i Stanisława Kaczmarza). 
Również dwa lata temu Maciej, chłopiec Jurków, wypędzając bydło na pole odkrył za domem Reginy kilkanaście dołków. Znajdowały się w nich wagle ponakrywane darnikami. Chłopak znalazł je na wygonie, nie potrafił też powiedzieć, kto owe dołki wykopal, ale do innych zeznających $w$ tej sprawie doszła już wersja bardziej demoniczna, zgodnie z którą Krawcowa wygrzebywała te dołki na cmentarzu ${ }^{16}$.

Inne zeznania dotyczyły bezskutecznych prób pożyczania przez Reginę od sąsiadów soli, mąki i innych żywnościowych produktów, a także ognia. Świadkowie twierdzili jednak, że przyczyną odmawiania pomocy nie były podejrzenia, które mieliby żywić wobec oskarżonej ${ }^{17}$.

O zarzutach kierowanych pod adresem drugiej podejrzanej - Heleny Gałczyny - niewiele wiadomo. Tylko jeden spośród świadków wspomniał, iż się z niej ludzie naśmiewajq, bo niedawnego czasu wyszla z domu czarno i jacyś przejeżdżający obok obcy ludzie [...] mówili na nia, że czarownica ${ }^{18}$. Nic nadzwyczajnego nie wniosły też zeznania dotyczące pobytu oskarżonych w więzieniu. Krawcowa i Gałczyna jedynie plakały i prosiły o przekupienie pana, by zechciał szybciej zakończyć proces ${ }^{19}$.

Był jednak jeszcze jeden dowód. Oto trzej świadkowie opowiadali przed sądem nie o czynach $\mathrm{i}$ podejrzanych zachowaniach obwinionych, lecz o ich pławieniu dokonanym jeszcze przed sprowadzeniem do wsi dobczyckiego sądu. Okazało się, że próbę wody zorganizowano niemal jak naukowy eksperyment; pławieniu dokonanym poddano bowiem nie tylko obie obwinione, ale także kilka innych kobiet nie podejrzewanych o czary. Cóż się okazało. Oto Galczyna i Krawcowa na wodzie plywaly i tonqci nie mogly; tak jedna, jak i druga utrzymywała się na powierzchni jako desczka. Tymczasem insze bialeglowy, które na próbe plawiono, wszytkie tonely; tonęly do dna-dodawali pozostali świadkowie. Ponoć też oskarżone po zakończonej próbie, gdy prowadzono je do dworu, usiłowały się tłumaczyć i wyjaśniać, że nie tonęły bo woda zburzona, metna byla. Obecny przy plawieniu Wojciech Kosialowic oświadczył jednak przed sądem, iż woda ta była zupełnie czysta ${ }^{20}$.

Po przesluchaniu świadków sąd przystąpil do wybadania oskarżonych. Obie kobiety stanowczo zaprzeczały, by kiedykolwiek bawiły się czarami lub zabobonami, zaś Regina Krawcowa dodatkowo powtórzyła wobec

${ }^{16}$ PAN Kr. 594, k. 106-106v.: zeznania Macieja chłopca Jurkowego, Ewy Jaźwcowej i jej komornicy Maryny oraz Ignacego Jamki i Stanisława Przybysza.

${ }^{17} \mathrm{~Np}$. odmowa użyczenia ognia wynikala z przesądu, zgodnie $z$ którym ludzie nie radzi daja ognia w świety Wojciech (PAN Kr. 594, k. 106 - zeznania Macieja Dybka, jego żony Teresy i Jadwigi Jamczyny).

18 PAN Kr. 594, k. 107: zeznanie Macieja Włodarza.

${ }^{19}$ PAN Kr. 594, k. 106v.: zeznania służącej we dworze Zolii i stróża Jana Kruczka.

${ }^{20}$ PAN Kr. 594, k. 107: zeznania Jakuba Lencowskiego, Stanisława Młynarza i Walentego Kosialowica, zob. też zeznanie Macieja Włodarza. 
sędziów znane nam już jej wyjaśnienie, dotyczące powstania osadu w garnku $\mathrm{z}$ mlekiem ${ }^{21}$.

Wysłuchanie oskarżonych stanowiło ostatni już etap postępowania przed wydaniem wyroku. W kończącym sprawę dekrecie sąd dał wiarę nie przyznającym się do winy kobietom, uznając, że dowody przeciwko nim przemawiające nie są dostateczne, zaś w podstawowej dla sprawy kwestii przemienionego rzekomo mleka najwyraźniej zgodził się z Reginą Krawcową, która plugastwo w tym mleku [...] nieochędostwu [...] swemu przypisuje. Sędziowie mogli też powołać się na samego poszkodowanego Michala Kanię, który zdarzenia owego za czary nie poczyta[1], podobnie zresztą jak $\mathrm{i}$ inni świadkowie pod przysięgą zeznający, iż o obwinionych nic zlego nie rozumieja ${ }^{22}$.

Pozostawal jednak problem utrzymywania się podejrzanych na wodzie podczas próby pławienia. Sąd musial $w$ tej sprawie zając jakieś stanowisko i rzeczywiście wypowiedział się w sposób bardzo stanowczy. Stwierdził mianowicie, że próba wody nie znajduje podstaw w prawie magdeburskim, a co więcej - prawo kościelne (a sprawy o czary przecież do sądów duchownych należą) zabrania takich eksperymentów. Stąd też zdecydowanie odrzucil dowód, który - jak się wydaje - w oczach wnoszącego sprawe uchodził za koronne świadectwo winy oskarżonych ${ }^{23}$.

3. Do tej pory znaliśmy głosy staropolskich pisarzy negatywnie osądzających plawienie domniemanych czarownic, np. bardzo ostro atakował takie próby autor wydanej w 1639 r. Czarownicy powolanej, krytycznie wypowiadal się o nich także późniejszy chełmiński prawnik Jakub Czechowicz ${ }^{24}$. Wiedzieliśmy

${ }^{21}$ PAN Kr. 594, k. 107-107v.

${ }^{22}$ PAN Kr. 594, k. $107 \mathrm{v}$.

${ }^{23}$ Co się tycze, jak świadectwa zeznaly, ze utonąc nie mogly, a insze tonely, ten dokument $i$ świadectwo, jako z prawa majdeburskiego fundamentu nie majqcy, $i$ owszem prawo duchowne (do którego causae maleficii, incantationis et magiae secundum statutu Regni Anno Domini 1543 sancita pertinent) has supernatationis in aquis prohibet, tenże sqd niniejszy mediante sententia sua annihilat et reprobat (PAN Kr. 594, k. 107v.).

${ }^{24}$ Czarownica powolana abo krótka nauka i przestroga z strony czarownic zebrana z rozmaitych doktorów, tak w prawie Bożym, jako i swieckim bieglych dla ochrony $i$ poratowania sumnienia osobliwie na takie sqdy wysadzonych, Poznań 1639, s. 63-71 (pytanie VII); zob. także drugie wydanie tej książki, Gdańsk 1714, s. 51-57; J. Cze ch ow ic z, Praktyka kryminalna to jest wzór rozważnego i porzqdnego spraw kryminalnych sadzenia, Chełmno 1769, s. 211-212; por. B. B a r a nowski, Procesy czarownic..., s. 63, 94-95; J. R o s en bla t t, Czarownica powolana. Przyczynek do historyi spraw przeciw czarownicom $w$ Polsce, Warszawa 1883, s. 47-48; W. Smoleński, Przewrót umyslowy w Polsce wieku XVIII. Studia historyczne, oprac. A. Wierzbicki, Warszawa 1979, s. 106-107; Z. Zdrójk owski, "Praktyka kryminalna" Jakuba Czechowicza. Jej źródla i system na tle rozwoju wspólczesnego prawa karnego zachodniej Europy, Toruń 1949, s. 57. 
też o opinii Andrzeja Komonieckiego - wójta żywieckiego, który, komentując pławienie przeprowadzone $w$ pobliskiej wiosce, nazwal je dziwowiskiem, które wedle prawa dowodem nie bylo ${ }^{25}$. Historykom prawa znane było również stanowisko Sądu Wyższego Prawa Niemieckiego na Zamku Krakowskim, który to sąd w 1645 r. określił próbę wody jako dowód podsunięty przez diabla ${ }^{26}$. W naszym wypadku mamy natomiast do czynienia $z$ orzeczeniem sądu pierwszej instancji, $i$ to sądu małego miasteczka. Trudno oczywiście na podstawie jednego tylko wyroku stwierdzać, że argumenty prawników i zarządzenia władz rzeczywiście trafiały do sędziów orzekających w sprawach o czary. Podjęta w 1689 r. w Gdowie decyzja mogła być wyjątkowa ${ }^{27}$, wskazuje ona jednak na konieczność zachowania daleko idącej ostrożności w formułowaniu wniosków. Wspomnieliśmy wcześniej o wątpliwościach co do częstotliwości wykorzystywania pławienia w sprawach o czary. Przykład z Gdowa każe dodatkowo zapytać o rolę tegoż pławienia w procesie. Już zresztą B. Baranowski zauważył, że próbom poddawano podejrzane zazwyczaj przed rozpoczęciem formalnego postępowania sądowego ${ }^{28}$. Uznanie pławienia za istotny składnik procesu - jak chcą podręczniki - wymagaloby zatem ustalenia, czy sądy miejskie rozpatrujące sprawy o czary rzeczywiście ex post akceptowały owo zarządzane przez dziedzica lub wiejskie władze samorządowe puszczanie na wodę, a także, czy wyniki prób miały wpływ na przebieg postępowania i ostateczną decyzję sądu.

4. Tego wszystkiego nie wiemy. Nie jest to zresztą jedyny nie do końca wyjaśniony problem związany ze ściganiem przestępstwa czarów w Polsce. Oczywiście, procesy czarownic od dawna przykuwały uwage historyków,

${ }^{25}$ A. Komonieck i, Chronografia albo Dziejopis żywiecki, wyd. S. Grodziski i I. Dwornicka, Żywiec 1987, s. 267 (1698 r.); por. B. B a ran owski, Procesy czarownic..., s. 95.

${ }^{26}$ Zob. K. Buk owska-Gorgoni, Procesy o czary..., s. 159, a zwłaszcza tekst wyroku na s. 165 ( $\mathrm{nr}$ 7): Na plawienie tych bialychglów in eo passu patrzyć nie potrzeba, bo takowe plawienie jest quaedam coniectura vel indagatio superstitiosa, iże nie żadnemi prawami wynaleziona, ale raczej diabolica suggestione ad indagandam in talibus veritatem iudicibus prudentibus podana, którq sacri canones et iura civila kondemnowaly $i$ onej serio, aby jej $w$ żadnych sqdach $i$ urzedach nie zażywano, zakazaly.

${ }^{27}$ Zważmy, że sẹdziów w Dobczycach cechowała daleko posunięta rozwaga; również w przypadku innych spraw o czary nie byli oni skłonni do pochopnego dawaniu wiary oskarżeniom, starali się odróżniać „czarostwo" od magii i innych podejrzanych zachowań. Zob. PAN Kr. 591, k. 40v.-41 (1670 r.), 109v--11 (1675 r.); PAN Kr. 594, k. 1-3v. (1687 r.). Należałoby też zaznaczyć, że zaledwie 15 lat wcześniej, w niezbyt przecież odległych Słomnikach, w wątpliwej dowodowo sprawie sędziowie uznali, że utrzymywanie się obwinionej na wodzie jest wielki dokument do czarów i skazali podejrzaną kobietę na ścięcie (W. Si a rk ow ski, Materialy..., s. 35, nr I).

${ }^{28}$ B. Baranowski, Procesy czarownic..., s. 91-92. 
zgromadzono zwłaszcza wiele informacji o wierzeniach i zwyczajach ludowych, które legły u podstaw owych procesów, opisywano też składane w ich trakcie zeznania. Badania te pozwalają na określenie istoty „czarostwa"29, dysponujemy również danymi na temat kar stosowanych za to przestępstwo ${ }^{30}$. Przynajmniej z grubsza znana jest też geografia procesów, częstotliwość ich występowania w różnych regionach Rzeczypospolitej ${ }^{31}$. Jednak nie potrafimy już np. określić, jaką część obwinionych stanowili mężczyźni ${ }^{32}$. Informacje o udziale obrońców $w$ procesach o czary $^{33}$ nakazują jeszcze raz uważnie zastanowić się nad pozycją oskarżonego i jego prawem do obrony. Dość częste, przynajmniej w Małopolsce, przypadki pozwalania obwinionym na składanie przysięgi oczyszczającej ${ }^{34}$, w zasadzie równoznacznej $\mathrm{z}$ uniewin-

${ }^{29}$ Zob. np. B. Baranowski, Procesy czarownic..., s. 124-168; K. Koranyi, Czary w Polsce, [w:] Pamiętnik II Zjazdu Slowiańskich Geografów i Etnografów w Polsce w r. 1927, t. II, Kraków 1930, s. 195-196; te nże, Eysa góra. Studium z dziejów wierzeń ludowych w Polsce w XVII i XVIII wieku, Lud 1928, Ser. II, t. VII (ogólnego zbioru t. XXVII), s. 57-72; W. M a ise1, Poznańskie prawo karne do końca XVI wieku, Poznań 1963, s. 211-216; F. O.[lszewski], Przesladowanie czarów w dawnej Polsce, [w:] Album uczqcej sie mlodzieży polskiej poświęcone Józefowi Ignacemu Kraszewskiemu z powodu jego pięćdziesiecioletniej dzialalności literackiej, Lwów 1879, s. 493-503.

${ }^{30}$ Np. B. B a ra nowski, Procesy czarownic..., s. 117-122; W. M a is el, Poznańskie prawo..., s. 210-213.

${ }^{31}$ B. B a ra now ski, Procesy czarownic..., s. 22-28, 30. Zob. jednak uwagi Janusza T a z bir a (Procesy o czary, Odrodzenie i Reformacja w Polsce 1978, t. XXIII, s. 176), który uznal, iż kwestia ta wymaga jeszcze gruntownych badań.

${ }^{32}$ Por. przykłady procesów wytaczanych mężczyznom lub chłopcom podejrzanym o czary, czy też uprawianie magii: rkps AGAD, Biblioteka Baworowskich, sygn. 252 (Grodzisk Wielkopolski), k. 20v.-2l (1710 r.), 89-92 (1737 r.); rkps w Archiwum Państwowym w Przemyślu, Akta miasta Przemyśla, sygn. 85, s. 9-14 (1718 r.), 205-214 (1741 r.); H. H ock e n beck, Hexenbrände in Wongrowitz, Zeitschrift der Historischen Geselschaft für die Provinz Posen 1894, R. IX, s. 176; J. J od k ow ski, O czarodzieju Znaku na inkwizycyi w Grodnie w I69I roku $i$ o ziolach czarodziejskich, Lud 1931, Ser. II, t. X (ogólnego zbioru t. XXX), s. 202-206; L. A. J u cewicz, Wspomnienia..., s. 187-194, 203-21l (Dodatek C: Dekrety na czarowników, nr III - 1695 r., V - 1696 r.). W różnych okolicach zachodniej Europy udział mężczyzn jako oskarżonych w procesach o czary wahał się od 5 do przeszło $40 \%$ (por. wyliczenia przedstawione $\mathrm{w}$ pracach Jeana Delumeau, Strach $w$ kulturze Zachodu XIV-XVIII w., przeł. A. Szymanowski, Warszawa 1986, s. 338-339, i Briana P. L e v a ck a, Polowanie na czarownice w Europie wczesnonowożytnej, przeł. E. Rutkowski, Wrocław-Warszawa-Kraków 1991, s. 146-147, zob. teź przyp. 17 na s. 168).

${ }^{33}$ Zob. rkps w Archiwum Państwowym w Krakowie [dalej: APKr.] AD 116 (Nowy Sącz), s. $399-419$ (1670 r.); APKr./W. AD 6 (Biecz), s. 127-149 (1644 r.); por. też W. Uru sz czak, Proces czarownicy w Nowym Sązu w 1670 roku. Z badań nad miejskim procesem karnym czasów nowożytnych, [w:] Historia prawa. Historia kultury. Liber memorialis Vitoldo Maisel dedicatus, Poznań 1994, s. 199.

${ }^{34}$ Zob. np. APKr. Akta miasta Kazimierza [dalej: AMKaz.], sygn. 266, s. 340-344 (1610 r.); APKr. AMKaz. 267, s. 13-14 (1611 r. - przysięga ostatecznie darowana przez powoda); APKr./W. AD 6 (Biecz), s. $216-247$ (1655 r.); por. też AGAD, Nabytki niedokumentowe 
nieniem, świadczyłyby $z$ kolei, że podejrzany o czary nie zawsze znajdował się na z góry straconej pozycji. W sumie więc zagadnienie represji „,czarostwa” w Polsce wymaga jeszcze wielu badań.

Oddziału I, sygn. 58 (Krzemieniec), s. 52-55 (1747 r.). O podobnych przypadkach w Nowym Wiśniczu w latach 1688 i 1709 r., oraz o calkowitym uniewinnieniu oskarżonej w 1622 r. zob. K. Kaczmarczyk, Proces o „czarostwo" w r. 1688 i 1689, Lud 1901, t. VII, s. 315-316; tenże, Przyczynki do wiary w czary, Lud 1907, t. XIII, s. 330-332, zaś o odmowie osądzenia czarownicy przez władze miasta Krościenka J. R a facz, Podejrzenie o czary w Krościenku, Lud 1914-1918, t. XX, s. 302-303. Zob. też Z. Pazdro, Proces $o$,perepiczke", Lud 1900, t. VI, s. 275-276. 